\title{
Hopes and fears of teacher candidates concerning the teaching profession
}

\author{
Daniela Creţu $^{1, *}$ \\ ${ }^{1}$ Lucian Blaga University of Sibiu, Teacher Training Department, 34 Calea Dumbrăvii 550324 Sibiu, \\ Romania
}

\begin{abstract}
Romanian university students have the opportunity to enroll in the education program for the teaching profession starting with their first year at the university. Most undergraduates choose the education program for the teaching profession, although some of them do not see themselves as teachers. The schooling experiences, the motivation for entering the teacher education programs, the initial teacher education experiences and their future plans can be important factors in considering the perspective of becoming a teacher or not. Focused on a future orientation, the goal of this study was to investigate teacher education candidates' hopes and fears concerning a possible career as teacher. Using an open-ended questionnaire as a research tool, a qualitative analysis was made on the hopes and fears expressed by the teacher candidates. Our findings showed different categories of hopes and fears and generated an enriched understanding of teacher candidates' views on this subject. The study can be a valuable support for teacher educators preoccupied to understand teacher candidates' perceptions and to assist them in getting closer to their ideals by improving the education program.
\end{abstract}

\section{Introduction}

Teacher education programs have an essential role in the professional development of future teachers- who are confronted with complex requests in a world with an accelerating dynamic. Romanian university students have the opportunity to enroll in the education program for the teaching profession beginning with their first year at the university. Most students enrolled in various study programs also choose the training program for the teaching profession, although not all of them are convinced that they want to become teachers. Becoming a teacher is not an easy decision for those interested in the profession. The schooling experiences, the motivation for entering the teacher education programs, the initial teacher education experiences and the future plans can be important factors in considering the perspective of becoming a teacher or not.

The perceptions and beliefs of teacher candidates about the work of teachers and the specifics of this profession are influenced by past and present experiences. When we say past experiences, we talk about the learning situations generated by the interactions with

\footnotetext{
*Corresponding author: daniela.cretu@ulbsibiu.ro
} 
dozens of teachers from different fields throughout the 12 years of school, as former students. Present experiences are related to their initial teacher education, which begins in their first year at the university. In the university where this work was conducted, teacher education involves a three to five-year undergraduate course in the specific field chosen by the student, along with a three-year pedagogy program. Within this teacher education program, students can study disciplines, such as: Educational Psychology, Pedagogy I (Education and Curriculum), Pedagogy II (Instruction and Assessment), Specialty Didactic - the specialty (major course), Educational Management, Pedagogical practicum and Computer Assisted Training. Such a program has the purpose to support the development of professional competencies that a teacher needs. The fact that most students choose this program is proof that their future plans include - as a priority or, in some cases, as a safety net- the possibility of working as teachers.

\section{Theoretical background}

Based on the past and the present experience, thinking about the future can provide the context for analyzing options, setting goals, for commitment, for identifying hopes and fears regarding the teaching profession. According to Malmberg \& Norrgard, hopes include aspirations, desires, and goals to achieve, while fears include things which we want to avoid [1]. Both hopes and fears shape the behavior to fulfill goals or avoid situations that are not perceived as pleasing. Hope expresses a desire for a better condition in the future, commonly associated with a positive, successful, desired image of the self, while fear is related to anxiety about a worse or undesirable condition in the future.

There are studies that investigate the problem of hopes and fears of future teachers regarding the teaching profession. We are presenting some of the studies which constituted a real support in the research stage of this investigation.

Markus and Nurius theory of possible-selves [2] provides a conceptual link between cognition and motivation, by taking into consideration individuals' ideas of what they might become, what they would like to become, and what they are afraid of becoming. Possibleselves are the cognitive components of hopes, fears, goals, and threats. According to Markus and Nurius possible selves are the ideal selves that we would very much like to become. They are also the selves we could become, and the selves we are afraid of becoming [2]. This theory helps to focus on the students'views of themselves in the future.

Hamman et al. [3] suggest that examining teachers' views in terms of possible-selves provides a better understanding of their present identity, and also of their identity in the future. In their study, Hamman et al. explored expected and feared possible selves of beginning teachers and identified four main categories: interpersonal relationships, classroom management, instructional strategies, professional qualities [3].

Johnson [4] considers that a teacher's knowledge and beliefs have a tremendous impact on how they view themselves as teachers, what they learn from their professional course work, how they reason about their teaching, and how and why they teach the way they do. Hamilton and Pinnegar [5] suggested that "who our students are, what they know and believe, and what experiences and talents they bring with them is an important but often overlooked component of teacher education" (p. 237).

In their study about the intern teacher development during an internship program in teaching, Conway \& Clark [6] consider that'attention to both hopes and fears together provides the opportunity to present a more balanced and expansive view of prospective teachers' actual experience and anticipations about learning to teach, than a concerns-only focus" (p.468). Recently, Shoyer \& Leshem [7] investigated teacher education candidates' hopes and fears concerning their future career as teachers. Two main categories related to hopes were identified: who the hopes are addressed to (self, the other pupil, or society) and 
the content of hopes (emotional, educational, or social). The analysis of fears revealed three main categories: emotional, cognitive and school-related.

In an investigation about teacher candidates' expectations and opinions related to practice school [8], Şimșek found that the anxieties and concerns were gathered under the following categories: personal, professional colaboration, school management, classroom management, student status, school status and parent colaboration.

Subscribing to the same field of interest, we believe that investigating students' hopes and fears about the teaching profession is a beneficial approach, useful for the following reasons: it can offer student teachers the opportunity to reflect on the teaching profession in a structured context; the teacher educators involved in the teacher education programs can discover and take into account the candidates' hopes and fears when building the foundations of the professional practice that students need to develop for their future teaching career, in terms of assisting them in moving closer to their aspirations and supporting their development in order to overcome their fears.

\section{Research design}

Based on a qualitative research design, this study had as a goal to explore teachers candidates' hopes and fears regarding the teaching profession. Two research questions guided the investigation: What are the teacher candidates' hopes about the teaching profession? and What are the teacher candidates' fears about the teaching profession?

An open-ended questionnaire was used as an investigation tool. The first part of the questionnaire was related to personal details such as: age, gender, study major and the intention of becoming or not a teacher. The second part contained two open-ended questions, as follows:

1. What are your hopes about the teaching profession? Identify them and comment on them. 2. What are your fears about the teaching profession? Identify them and comment on them.

The questions were simple and wide, in order to allow the participants to express themselves as freely and sincerely as possible. Student teacher participants were recruited at the end of an exam, during the assessment period (January- February 2017). They were informed about the goal of the research and volunteers were given the questionnaire to complete. With no time limit, the participants were invited to write as many hopes and fears as they wished.

A total of 223 teacher candidates enrolled in a three years teaching program at Lucian Blaga University participated in this study. At the time of this study, 35.53\% of participants were at the end of the first semester of their second year in the teaching education program and $64.46 \%$ were at the end of the first semester of their third year in the teaching education program. The latest category also had the experience of didactic practice for a semester. The study had students from the following majors: Letters - Literature and Foreign Language $(n=86)$, Engineering $(n=42)$, Sciences $(n=30)$, Social Sciences $(n=23)$, Theology $(n=23)$, Medicine $(n=21) .70 .85 \%$ of participants were female and $29.14 \%$ were male, aged twenty to forty-six.

\section{Results and discussion}

The content analysis technique was used for the undergraduates' responses to the two questions. Specific codes emerged from the analysis. Thus, we identified ten categories for hopes and for fears, each of them with more subcategories. We begin with the analysis of the hopes. Their frequency is presented in Table 1. Some of these categories were similar to 
some already identified in previous investigations and were defined accordingly. Other categories that resulted from the students' answers analysis were added to them.

Table 1. Teachers candidates' hopes concerning the teaching profession

\begin{tabular}{|l|r|}
\hline Hopes (H) Category/ Subcategories & Frequency \\
\hline $\begin{array}{l}\text { H1: Generic motives/ Teaching mission - help children to learn/to } \\
\text { succeed, support child development, inspiring/motivating the new } \\
\text { generation, be a model }\end{array}$ & 104 \\
\hline $\begin{array}{l}\text { H2: Interpersonal relationships - with pupils (communication, receive } \\
\text { respect); with parents (communication, receive respect); with other } \\
\text { teachers/colleagues (communication, be accepted, receive support) }\end{array}$ & 73 \\
\hline $\begin{array}{l}\text { H3: Perception of the teaching profession - increasing social status, } \\
\text { increasing financial status, employment (finding a job) }\end{array}$ & 69 \\
\hline $\begin{array}{l}\text { H4: Classroom management - maintain discipline, handle difficult } \\
\text { behavior or situations, create positive learning environment }\end{array}$ & 54 \\
\hline $\begin{array}{l}\text { H5: Identity/personal issues - vocation, suited for teaching, personality } \\
\text { traits (friendly, empathetic, energetic, creative, patient) }\end{array}$ & 39 \\
\hline $\begin{array}{l}\text { H6: Instruction - instructional strategies (variety, adequacy), students } \\
\text { centered instruction }\end{array}$ & 33 \\
\hline $\begin{array}{l}\text { H7: Professional development - life-long learning, succeeding in } \\
\text { professional exams }\end{array}$ & 32 \\
\hline $\begin{array}{l}\text { H8: School conditions - improving school conditions, teaching - learning } \\
\text { equipment, school climate/ prestige }\end{array}$ & 26 \\
\hline H9: Curriculum - less theoretical, more practical, less congestion & 18 \\
\hline H10: School system - less bureaucracy, more stability & $\mathbf{4 6 3}$ \\
\hline Total & \\
\hline
\end{tabular}

Out of 779 statements, $463(59.43 \%)$ were related to hopes and $316(40.56 \%)$ were related to fears. The analysis of hopes $(\mathrm{H})$ revealed ten major categories. Next, these categories are presented with a brief description and some examples were extracted from the questionnaires completed by the undergraduates.

H1: Generic motives - generic reasons related to pre-service teachers' goals of becoming a teacher and to the teaching career choice [9]: "I want to work with children, help them learn, understand the world, to support them in forming character and choosing values, also to prepare them for the future."

H2: Interpersonal relationships - interactions with persons or groups found within a school [3]: "I want to have a good communication with students, based on trust and respect."

H3: Perception of the teaching profession - how the teaching profession is perceived [9]: "I wish the teaching profession would get more respect in our society."

H4: Classroom management - management of the classroom, discipline issues [3]: "I hope I will be able to manage difficult situations and I'll have patience with disruptive students."

H5: Identity/personal issue - self-perceptions about teaching abilities and identity related motives [9]: "I am an energetic and communicative person and I hope this will help me in my teaching career."

H6: Instruction - the use of strategies, the focus on instructional process [3]: "I hope I can use the methods that are appropriate for the children I'll work with. They are so different."

H7: Professional development - continuing learning process: "If I become a teacher I expect it to be a continuous learning experience." 
H8: School conditions - characteristic of schools in terms of instructional facilities, climate, prestige: "I wish I'd work in a school where I'll have optimal work conditions and the necessary means to teach"

H9: Curriculum - characteristic of curriculum: "I would like a less congested school curriculum that leaves more freedom to the teacher."

H10: School system - characteristic of school system: "I would like a more stable teaching system, that doesn't change so much each year."

The results of research demonstrate that teacher candidates have a lot of diverse hopes concerning the teaching profession. Most of these $(22.46 \%)$ are connected to the desire to support pupils in their development and to be a role model for them, which demonstrates their good understanding of the teacher's mission. $15.76 \%$ of their hopes are linked to the possibility of developing positive relationships- with the students but also with the student's parents and with their fellow teachers. Teacher candidates hope $(14.90 \%)$ in an improvement of the social and financial status of the teaching profession and the possibility to work in a good school (or one that is closer to home). Teacher candidates hope to manage the classroom appropriately $(11.66 \%)$, to capitalize on their abilities/personal strengths when teaching $(8.42 \%)$, to offer quality teaching- student centered- by choosing varied and optimal methods $(7.12 \%)$, to continuously grow professionally $(6.91 \%)$. Also, teacher candidates wish for better working conditions in schools $(5.61 \%)$, a less congested and less theoretical curriculum, with more focus on practical aspects (3.28\%), less bureaucracy and more stability in the educational system $(3.23 \%)$.

Out of 463 hopes, $262(56.58 \%)$ are related to the self and $201(43.41 \%)$ related to the other. The students have demonstrated understanding that they need to personally resonate with the teaching profession, but also consider the external factors that influence it.

Regarding the fears (F) and the problems they believe they will have to face, the analysis revealed the same categories as in the case of hope, with the addition of another one- having no fear. The frequency of each category and their sub-categories are presented in Table 2. Next, the fears categories are presented with a brief description and some examples extracted from the questionnaires completed by the undergraduates.

F1: Perception of the teaching profession - negative or unsatisfactory perception of the teaching profession: "Unfortunately, the teaching profession is not appreciated in our country and I am afraid I can't support even myself with a beginner teacher's payment".

F2: Interpersonal relationships - negative or a poor quality of interaction with persons or groups found within a school [3]: "I am afraid the new generations of students are disrespectful to teachers."

F3: Classroom management - being ineffective at orchestrating the matters of discipline, student behavior or classroom procedures [3]: "I fear I won't be able to handle more delicate situations / problematic student behavior (violence, behavioral disorders) ."

F4: Identity/personal issues - negative self-perception about teaching abilities and behavior, undesirable characteristics: "I don't think I'd be a good teacher. I often lose my patience."

F5: Generic motives/ Mission of teaching - fears about failing the teacher' mission: " $I$ am afraid I will not be able to support my pupils in the learning process."

F6: Instruction - being ineffective with instruction, using ineffective strategies, or not being successful in some aspect of the instructional process [3]: "I don't know if I'll be able to keep the students' attention for an entire class. "

F7: Professional development - obstacles, difficulties in the professional development: "I know a teacher has to take a lot of exams. I am kind of scared of this perspective".

F8: School conditions and management - unsatisfactory school characteristics, in terms of instructional facilities, climate or school management: "I am afraid I am going to end up in a school that is lacking even the minimal teaching conditions." 
F9: School system - negative aspects of the school system: "I am rather scared of the many changes in the system, confusing for both teachers and students."

F10: Curriculum - negative/unsatisfactory characteristic of curriculum: "The curriculum has too much content, I am afraid I won't be able to get through all of it."

No fear: "I have no fears regarding the teaching profession."

Table 2. Teachers candidates' fears concerning the teaching profession

\begin{tabular}{|l|r|}
\hline Fears Category/ Subcategories & Frequency \\
\hline $\begin{array}{l}\text { F1: Perception of the teaching profession - low financial status, low } \\
\text { social status, employment (difficult to find a job) }\end{array}$ & 68 \\
\hline $\begin{array}{l}\text { F2: Interpersonal relationships - with pupils (being disrespected, } \\
\text { students' lack of interest, not being understood, not being accepted or } \\
\text { liked); with parents (barriers in communication, not being respected, lack of } \\
\text { interest and involvement from parents); with other teachers/colleagues (not } \\
\text { being accepted or appreciated, not receiving support) }\end{array}$ & 59 \\
\hline $\begin{array}{l}\text { F3: Classroom management - difficulties in maintaining class discipline, } \\
\text { manage difficult behavior or situations, classroom size (too many students), } \\
\text { being too authoritarian or too permissive }\end{array}$ & 47 \\
\hline $\begin{array}{l}\text { F4: Identity/personal issue - not good enough, losing patience, tiredness, } \\
\text { stress, loss of health, negative emotions (scared, fear of public speaking) }\end{array}$ & \\
\hline $\begin{array}{l}\text { F5: Generic motives/Teaching mission - fear of failure to help the } \\
\text { students to learn and develop, not inspiring/motivating new generation }\end{array}$ & 30 \\
\hline $\begin{array}{l}\text { F6: Instruction - difficulties in instructional design, difficulties in } \\
\text { capturing and maintaining attention, failure to use effective strategies, } \\
\text { working with pupils with special educational needs }\end{array}$ & 25 \\
\hline $\begin{array}{l}\text { F7: Professional development - routine, self-sufficient, not keeping pace } \\
\text { with changes, failing in professional exams }\end{array}$ & 24 \\
\hline $\begin{array}{l}\text { F8: School conditions and management - lack of school facilities, } \\
\text { negative school culture/ prestige, ineffective school management }\end{array}$ & 18 \\
\hline F9: School system - to much bureaucracy, to many changes & 19 \\
\hline F10: Curriculum - to congested, too theoretical & $\mathbf{3 1 6}$ \\
\hline Total & \\
\hline No fear & \\
\hline
\end{tabular}

The findings of the research demonstrate that the majority of teacher candidates have many, diverse fears concerning the teaching profession. Only seven of them reported no fears. Most of the fears $(21.51 \%)$ are connected to how the teaching profession is perceived: low financial and social status, hard to find a position in the system. $18.67 \%$ of fears are linked to interacting with future pupils, parents or colleagues. Students consider that the new generations of students are more disrespectful and lack an interest for learning; also, they fear being disliked or misunderstood. Regarding the teacher - parent relationship, candidates are worried that they won't be able to properly communicate with parents due to their lack of respect for the teaching profession. Some talk about the fear of not being accepted or appreciated by their fellow teachers. Students fear the responsibility of managing student classrooms, maintaining discipline despite having too many students in a class, being too authoritarian or too permissive (14.87\%). Some students don't feel good enough/ prepared enough for being teachers, others lack patience, are afraid of the stress resulting from the job demands, or are afraid of public speaking and failing due to nerves. They have the fears of not being able to help the students to learn and develop or not being a good role model $(7.91 \%) .7 .59 \%$ of the fears expressed by teacher candidates are related 
to specific instruction issues, such as: planning classwork instruction, capturing and maintaining student's attention, using effective teaching strategies or working with special educational needs pupils). Some fears appear in smaller percentages, such as those relating to self-sufficiency, routine, not being able to pass the multitude of exams teachers have to take during their careers $(6 \%)$, fears about the bad working conditions in some schools, negative climate or bad management (5.69\%), fears concerning the bureaucracy and the many changes in the system (4.74\%), fears about the congested, over-loaded, mostly theoretical curriculum $(3.48 \%)$.

Out of 316 fears, $145(45.88 \%)$ were related to the self and $171(54.11 \%)$ related to the other. Students are more afraid of external factors, such as: professional status, students, parents, colleagues, system, curriculum, school conditions and management, than they are of internal factors. In the end, only $56.50 \%$ of the participants in this study have expressed a firm option for becoming teachers, $38.56 \%$ are not decided, and $4.94 \%$ don't want to become teachers, even though they are all taking the same teacher - training program. Some aspects have indeed contributed to making the teaching profession less attractive: the continuous degradation of the teacher's social status for the last 25 years in Romanian society, the growth of violent acts in schools, the worrisome lack of motivation recorded in students, the abandonment of the educative attributions of parenthood in some parents, the lack of continuity and coherence in school policies, the poverty of some schools, excessive bureaucracy.

It is necessary that teacher candidates develop a realistic understanding of the teaching career. Thinking about the future, realizing the pleasant aspects, considering the challenges and the difficulties associated with the didactic profession is an useful exercise for undergraduates that can prepare them for the transition from the university to the outside world. The reflection exercise allowed the students to explore- both cognitively and emotionally- their own universe (hoped-for and feared possible selves), to become aware of the complexities of the teaching profession.

We consider that capturing the teacher candidates' hopes and fears concerning the teaching profession is a great resource for teacher - educators preoccupied to tailor the teacher programs to meet the individual needs of future teachers. Who our students are, what they know and believe, what they hope or fear are important issues which should be taken into consideration in teacher education program. These hopes and fears may be an indication of the effect the educator preparation programs, working within a specific context, have had and also of the influence past interactions with the school system and their teachers have had on them. The experiences they have had may have influenced their ability to consider what they want to become or find and what they want to avoid.

Since the past can't be recovered, we can focus on modifying the present for a better future. Conway \& Clark [6] consider that "hopes and fears alone or together can be the basis for both a supportive and challenging conversation with student teachers about their beliefs and motives, about classrooms, schools, students, learning and teaching, and relationships... a focus on both aspirations and concerns, within an inquiry approach to teaching, can provide a helpful lens with which to understand and support the development of prospective teachers" (p. 468).

\section{Conclusions}

The study of hopes and fears of teacher candidates regarding their future as teachers revealed their perceptions about themselves and about multiple aspects of the profession. More hopes than fears were expressed by participants. Ten categories for both hopes and fears, each of them with more subcategories, were extracted from the participants' responses. In their reflections, the candidates invoked both self-related and others-related 
aspects. When expressing hopes, self-related factors prevailed and when expressing fears there were more external-related factors to count in their answers.

The current investigation has limitations because is based on a one-time look at teachers candidates' hopes and fears. A longitudinal approach can be used for future research.

It is needed that teacher training programs tailor curricula and professional practices to meet the individual needs of future teachers. As teacher educators, we may value the candidates' hopes by building positive professional practices that can than be transferred towards building their early career. The enriched understanding of the undergraduates' fears can help the teacher educators to focus on giving specific support for overcoming them. It is true that some fears can't be checked by the intervention of teacher educators (such are those relating to the social and financial status of the profession, those concerning working conditions in schools, finding a good position, curriculum, the way the school system works), but others are under their direct influence (classroom management, communication in relationships, instruction, professional development).

Specific measures can be taken, for instance: enhancing class management exercises, more examples of dealing with difficult students exhibiting deviant behaviors (by case studies), creating more opportunities for students to practice public speaking (during seminars or student meetings, conferences), more micro-teaching practice for stimulating their presentation skills and for using various instructional strategies, more communication exercises in order to improve parent/ student communication (role- playing or scenario analysis), meeting with students, parents and other teachers before school practice or in other contexts, giving more attention to the problems inclusive education and teaching special needs pupils poses. Measures like these can support teacher candidates in overcoming their fears regarding a teaching career, reaching for their goals and preparing them for the school that they will possibly serve in the future.

\section{References}

1. L.E. Malmberg, S. Norrgard, J.of Adolescence 22, 33-47 (1999)

2. H. Markus, P. Nurius, Am. Psy. 41, 954-969 (1986)

3. D. Hamman, K. Gosselin, J. Romano, R. Bunuan, Teaching and Teacher Ed 26 (7), 1349-1361 (2010)

4. K. Johnson, Understanding Language Teaching: Reasoning in Action. (Boston: Heinle and Heinle Publishing Company ,1999)

5. M. L., Hamilton, S. Pinnegar, J., Teacher Ed 51 (3), 234-240 (2000)

6. P. F. Conway, C. M. Clark, Teaching and Teacher Ed., 19, 465-482, (2003)

7. S. Shoyer, S. Leshem, Cogent Education 3: 1139438 (2016)

8. C. Şimșek, Inter.J. Edu. Res.Technol 5 (2), 55-63 (2014)

9. M. M. Thomson, C. Palermo, Teaching and Teacher Ed. 44, 56-68 (2014) 